\title{
Influence of the pattern of peptide supply on microbial activity in the rumen simulating fermenter (RUSITEC)
}

\author{
Juan P. Russi, R. John Wallace and C. James Newbold* \\ Rowett Research Institute, Bucksburn, Aberdeen AB21 9SB, Scotland, UK
}

(Received 7 December 2000 - Revised 14 January 2002 - Accepted 7 February 2002)

\begin{abstract}
The source and pattern of $\mathrm{N}$ supply was varied in the rumen simulation technique (RUSITEC) in order to determine if continuous, rather than transient, availability of peptides was required for optimum ruminal fermentation. The energy source was fibre prepared from sugar-beet pulp. $\mathrm{N}$ was added as $\mathrm{NH}_{3}$ continuously infused (AC) or peptides (Bacto ${ }^{\circledR}$ Casitone, a pancreatic hydrolysate of casein; Difco Laboratories, Detroit, MI, USA) continuously infused (PC) or added as a single dose at the time of feeding (PS). Free peptides were detected in the fermenter liquid for $4 \mathrm{~h}$ after feeding in the AC treatment, for $10 \mathrm{~h}$ in the PS treatment, and at all times with the PC treatment. Treatments had no effect on DM degradation. Approximately $40 \%$ of the degradation occurred during the time no peptides were detected in the PS treatment. Microbial N flow tended to be higher with the peptide additions $(P<0 \cdot 061)$, with no significant difference between the two peptides treatments. The production of liquid-associated microorganisms (LAM) was higher in the PC treatment $(P<0 \cdot 05)$ and the proportion of LAM derived from $\mathrm{NH}_{3}$ lower $(P<0 \cdot 05)$. However, LAM only accounted for $20-30 \%$ total microbial population. Our main conclusion was that peptides had a small stimulatory effect on the fermentation, but there was no indication that synchrony of supply of energy and amino acid- $\mathrm{N}$ in the fermenter promoted a more efficient fermentation than non-synchronous supply. This conclusion must be qualified, however, because some $\mathrm{N}$ remained in the fibre and may have become available progressively as the fibre was digested by the micro-organisms.
\end{abstract}

\section{Synchrony: Microbial protein synthesis: RUSITEC}

It has been suggested that matching or synchronizing the supply of energy and $\mathrm{N}$ supply in the rumen may improve microbial growth (Johnson, 1976; Sinclair et al. 1993). However, experiments which have attempted to synchronize the release of $\mathrm{NH}_{3}-\mathrm{N}$ with energy supply to rumen micro-organisms by the infusion of energy or urea into the rumen have generally found little or no benefit in terms of microbial growth (Henning et al. 1993; Kim et al. 1999). Chamberlain \& Choung (1995) concluded that there was little benefit in maintaining a synchronized supply of $\mathrm{NH}_{3}-\mathrm{N}$ and energy release in the rumen, although they did suggest that more results were required on the synchronization of energy with other nitrogenous substrates, including peptides and amino acids.

Peptides and, to a lesser extent, amino acids accumulate in rumen contents in the early post-feeding period, the extent of the accumulation depending at least in part on the degradability of the dietary protein, and rapidly decline thereafter (Chen et al. 1987; Broderick \& Wallace, 1988).
The peptides which persist for longer periods are probably not degraded readily by rumen micro-organisms (Wallace \& McKain, 1990). Thus, when ruminant animals are meal-fed, little or no peptides will be available in rumen contents for microbial growth for much of the diurnal cycle. Numerous studies have demonstrated benefits to feeding pre-formed amino acids, either as free amino acids, peptides or proteins, in terms of increased microbial growth and/or fibre breakdown in the rumen (Hume, 1970; Maeng \& Baldwin, 1976; Maeng et al. 1976; Cotta \& Russell, 1982; Rooke \& Armstrong, 1989; Merry et al. 1990; McAllan, 1991). Cruz Soto et al. (1994) presented evidence which suggested that stimulation by peptides and amino acids will not always occur; peptides and amino acids benefited cellulolytic bacteria, but only when they were growing on cellobiose, not cellulose. In a later experiment, Chikunya et al. (1996) confirmed that the benefit of peptides would only be evident if the energy source supported a growth rate which enabled the organisms to

\footnotetext{
Abbreviations: AC, ammonia continuously infused; LAM, liquid-associated micro-organisms; PC, peptides continuously infused; PS, peptides as a single dose; RUSITEC, rumen simulating fermenter; SAM, solid-associated micro-organisms.

* Corresponding author: Dr C. James Newbold, fax +44 1224 716687, email cjn@ rri.sari.ac.uk
} 
respond to added peptides. However, given that peptides will only be available in the rumen for a short time after feeding, it may also be necessary to match the time at which peptides and energy are supplied to the rumen to maximize the stimulation in microbial activity.

The objective of the present study was to utilize the stable conditions of a fermenter to investigate how microbial protein synthesis responds to continuous, synchronous and asynchronous provision of peptides. Carro \& Miller (1999) recently used the rumen-simulating fermenter, RUSITEC, to investigate the effects of protein, peptides, amino acids and $\mathrm{NH}_{3}$ on rumen fermentation. The present study also used RUSITEC, and, given that the response of the rumen micro-organisms to peptides appears to be diet-dependent (Chikunya et al. 1996), the diet and conditions were held as closely as possible to those used by Carro \& Miller (1999).

\section{Materials and methods}

\section{Apparatus}

The fermenter was the semi-continuous system developed by Czerkawski \& Breckenridge (1977), known as the rumen simulation technique (RUSITEC). The nominal volume in each reaction vessel was $780 \mathrm{ml}$ and the dilution rate was set at $0 \cdot 80 \mathrm{~d}^{-1}$, the infused buffer being artificial saliva (McDougall, 1948) adjusted to $\mathrm{pH} 8.4$ and supplemented with $0.3,0.9$ and $0.7 \mathrm{mmol}$ isobutyric, isovaleric and $n$-valeric acids/l. Inocula for the fermentation vessels were obtained from a pooled sample of strained rumen contents and rumen solids removed $2 \mathrm{~h}$ after the morning feed from five rumen-cannulated sheep receiving $1.4 \mathrm{~kg}$ mixed diet/d (g/kg DM: grass hay 500.0, barley 299.5, molasses 100.0, white fishmeal 91.0, vitamin and mineral mixture 9.5) in two equal meals. Twelve vessels were set up as described previously (López et al. 1999). The basal diet used in RUSITEC consisted of supplemented fibre from sugar-beet pulp prepared as described later. The food for the fermentation vessels $(15 \mathrm{~g} / \mathrm{d})$ was provided in nylon bags $(110 \times 60 \mathrm{~mm}$, mean pore size $50 \mu \mathrm{m})$, which were gently agitated in the liquid phase. Normally, two bags were present at any time and one bag was replaced each day to give a $48 \mathrm{~h}$ incubation. In order to estimate the degradability of the diet additional bags containing $1 \mathrm{~g}$ basal diet (maximum of two additional bags per vessel at any time) were incubated for $3,9,12,24$ or $48 \mathrm{~h}$ as described later. While the bag was being changed, the vessels were flushed with $\mathrm{CO}_{2}$ to help maintain anaerobiosis. The experiment lasted for $22 \mathrm{~d}$, with all samples taken during the last $5 \mathrm{~d}$.

\section{Experimental diet and treatments}

Fibre from sugar-beet pulp was obtained by washing sugarbeet pulp (placed inside a cloth bag) in a washing machine with commercial detergent at $90^{\circ} \mathrm{C}$ for $2 \mathrm{~h}$. This procedure was repeated three times and the material obtained was washed again three times in the washing machine at $90^{\circ} \mathrm{C}$ for $2 \mathrm{~h}$ in the absence of detergent. Finally, the material was rinsed for $2 \mathrm{~h}$ in cold water and spun for
$10 \mathrm{~min}$ before drying at $60^{\circ} \mathrm{C}$ for $2 \mathrm{~d}$. Fibre prepared as described was supplemented with a commercial vitamins and trace elements mix $(1.3 \mathrm{~g} / \mathrm{kg}$; Norvite Feed Supplements, Insch, Aberdeenshire, UK)

Treatments were allocated at random to four vessels each and were: (1) $\mathrm{NH}_{3}$ continuously infused (AC): $1.712 \mathrm{~g} \mathrm{NH}_{4} \mathrm{Cl} / \mathrm{l}$ added to the infusion buffer; (2) peptides added as a single dose (PS): $612 \mathrm{mg} \mathrm{NH} \mathrm{NH}_{4} \mathrm{Cl} / \mathrm{l}$ added to the infusion buffer plus $1.285 \mathrm{~g}$ Bacto ${ }^{\circledR}$ Casitone (a pancreatic hydrolysate of casein; Difco Laboratories, Detroit, MI, USA) added in $5 \mathrm{ml}$ water to the vessels at the time of feeding; (3) peptides continuously infused (PC): $612 \mathrm{mg} \mathrm{NH}_{4} \mathrm{Cl} / 1$ plus $2.06 \mathrm{~g} \mathrm{Bacto}^{\circledR}$ Casitone (Difco Laboratories $) / 1$ added to the infusion buffer.

Infusion buffer was maintained at $4^{\circ} \mathrm{C}$ in iced water to avoid microbial growth. All treatments were designed to be isonitrogenous and to supply $280 \mathrm{mg} \mathrm{N}$ per vessel per d. $\mathrm{Na}_{2} \mathrm{SO}_{4}(177 \mathrm{mg} / \mathrm{l})$ was added to all treatment buffers $(\mathrm{N}: \mathrm{S}$ ratio $10: 1)$ to prevent growth limitation by $\mathrm{S}$. Based on the study of Carro \& Miller (1999) $1.8 \mathrm{mg}{ }^{15} \mathrm{NH}_{4} \mathrm{Cl}$ (99\% enriched; Sigma Chemical Co., Poole, Dorset, UK) was added to each vessel after $7 \mathrm{~d}$ of the experiment and thereafter ${ }^{15} \mathrm{NH}_{4} \mathrm{Cl}(3.67 \mathrm{mg} / \mathrm{l})$ was added to all infusion buffers.

\section{Experimental measurements}

During the last $5 \mathrm{~d}$ of the experiment, fermentation products were determined on samples taken from the liquid overflow. Saturated $\mathrm{HgCl}_{2}(10 \mathrm{ml} / \mathrm{d})$ was added to the overflow to prevent fermentation. Volatile fatty acids were determined by GLC using ethylbutyric acid as the internal standard as described by Stewart \& Duncan (1985). $\mathrm{NH}_{3}$ was measured by the phenol-hyprochlorite method of Whitehead et al. (1967). The volume of the overflow liquid multiplied by the concentration of fermentation products was used to calculate the daily output of fermentation products. Culture $\mathrm{pH}$ was measured using a $\mathrm{pH}$ electrode connected to a Russell $660 \mathrm{pH}$ meter (Russell pH, Auchtermuchty, Fife, Scotland, UK) in samples of fermentation fluid withdrawn at the time of feeding. The digestibility of the diet was estimated from the DM remaining in the bags after 3, 9, 12, 24 or $48 \mathrm{~h}$ incubation in the RUSITEC vessels. Bags were washed in a domestic washing machine for $20 \mathrm{~min}$ in cold water, in the absence of detergent, and allowed to dry to a constant weight at $60-70^{\circ} \mathrm{C}$ for $48 \mathrm{~h}$. The estimations of DM disappearance at different times were used to derive values describing the shape of the degradation curve according to the equation: $p=$ $a+b\left(1-e^{-c t}\right)$, where $p$ is the degradation after time $t$, $a$ is the intercept of the degradation curve at time zero; $b$ is the portion of the feed that will be degraded; $\mathrm{c}$ is the rate constant of degradation of $b$ (Ørskov \& McDonald, 1979). Data were fitted to the curve using the program fcurve (Macaulay Land Use Research Institute, 2001)

On two consecutive days, samples $(10 \mathrm{ml})$ of fluid from each vessel were taken $1 \mathrm{~h}$ before feeding (changing the $48 \mathrm{~h}$ bag for a new one), at the time of feeding $(0 \mathrm{~h})$ and $1,2,4,6,8,10$ and $24 \mathrm{~h}$ after feeding. Samples were centrifuged at $120 \mathrm{~g}$ for $5 \mathrm{~min}$ at $39^{\circ} \mathrm{C}$ and the resultant supernatant fraction was centrifuged at $28000 \mathrm{~g}$ for $20 \mathrm{~min}$ at 
$4{ }^{\circ} \mathrm{C}$. To remove protein from the sample, $1.25 \mathrm{ml}$ perchloric acid $(250 \mathrm{~g} / \mathrm{l})$ was added to the resultant supernatant fraction and the centrifugation was repeated. To neutralize the excess acid, $1.25 \mathrm{ml} 2 \mathrm{M}$-potassium carbonate was added to $5 \mathrm{ml}$ supernatant fraction and the sample was centrifuged again. Peptide concentrations were determined using fluorescamine (Broderick \& Wallace, 1988) in a fluorimeter (excitation $365 \mathrm{~nm}$, emission $450 \mathrm{~nm}$; Dynatec Fluorolite 1000; Dynex Labsystems, Ashfield, Middlesex, UK).

Samples for microbial counts were taken on two consecutive days at the time of feeding during the sampling period. Anaerobic methods (Hungate, 1966) were used to prepare media and to cultivate bacteria. Media were dispensed into Hungate tubes sealed with butyl rubber stoppers (Bellco Glass Inc., Vineland, NJ, USA). A sample of fermentation fluid $(20 \mathrm{ml})$ taken directly from the reaction vessel together with a sample of the digesta $(1 \mathrm{~g})$ remaining in the nylon bags incubated for the last $48 \mathrm{~h}$ were homogenized, under $\mathrm{O}_{2}$-free $\mathrm{CO}_{2}$, for $1 \mathrm{~min}$ using an MSE top-bladed homogenizer at full speed (MSE, London, UK). Serial 10-fold dilutions were prepared under $\mathrm{O}_{2}$-free $\mathrm{CO}_{2}$ for each sample by the anaerobic method of Bryant (1972) using an anaerobic diluent (Mann, 1968). Total viable bacteria were enumerated in roll tubes with a complex rumen contents plus sugars medium to which agar (20 g/l) was added (medium M2; Hobson, 1969), and these tubes were incubated for $72 \mathrm{~h}$ at $39^{\circ} \mathrm{C}$. Cellulolytic bacterial numbers were determined by a most-probable-number method based on the degradation of filter paper strips (Mann, 1968). Counts of ciliate protozoa were carried out microscopically in a counting chamber (Newbold et al. 1987).

\section{Preparation of fractions to measure ${ }^{15} \mathrm{~N}$ enrichment}

On two consecutive days, $400 \mathrm{ml}$ from the effluent of each vessel were mixed and homogenized in a blender at low speed for $1 \mathrm{~min}$ with their corresponding $48 \mathrm{~h}$ bag contents to provide total digesta. A subsample was stored at $-20^{\circ} \mathrm{C}$ and lyophilized to provide a total digesta pellet for $\mathrm{N}$ and ${ }^{15} \mathrm{~N}$ determinations.

Total digesta were used to isolate a total microbial pellet. Total digesta were strained through four layers of muslin. The strained liquid was then centrifuged at $500 \mathrm{~g}$ for $10 \mathrm{~min}$ at $4^{\circ} \mathrm{C}$, and the supernatant fraction was centrifuged again at $18000 \mathrm{~g}$ for $25 \mathrm{~min}$ at $4^{\circ} \mathrm{C}$. The pellet obtained was resuspended with $10 \mathrm{ml}$ distilled water and lyophilized.

Total digesta were also used to estimate the enrichment of ${ }^{15} \mathrm{~N}$ in $\mathrm{NH}_{3}$. Total digesta were acidified by the addition of TCA to a final concentration of $50 \mathrm{~g} / \mathrm{l}$ and centrifuged at $14000 \mathrm{~g}$ for $30 \mathrm{~min}$ at $4^{\circ} \mathrm{C}$. The ${ }^{15} \mathrm{~N}$ enrichment in $\mathrm{NH}_{3}$ was determined by recovering $\mathrm{NH}_{3}$ from acidified samples of rumen contents by adjusting the $\mathrm{pH}$ to $>10$ with $2 \mathrm{M}$ $\mathrm{NaOH}$ and distilling into $0 \cdot 1 \mathrm{M}-\mathrm{H}_{2} \mathrm{SO}_{4}$ in Conway units at $60^{\circ} \mathrm{C}$ for $2 \mathrm{~h}$ in the presence of $\mathrm{KMnO}_{4}$ (Conway, 1957). The acid solution was freeze-dried and analysed for ${ }^{15} \mathrm{~N}$. The $\mathrm{NH}_{3}$ concentration was determined in a separate assay as described earlier.

On the last day of the experiment, the nylon bag residues (two bags from each vessel, 24 and $48 \mathrm{~h}$ ) were incubated with $240 \mathrm{ml}$ methylcellulose in saline $(1 \mathrm{~g}$ methylcellulose $+9 \mathrm{~g} \mathrm{NaCl}$ in 1 litre distilled water) at $39^{\circ} \mathrm{C}$ for $30 \mathrm{~min}$ to elute attached micro-organisms (Minato \& Suto, 1978). Then $500 \mathrm{ml}$ cold $\left(4^{\circ} \mathrm{C}\right)$ methylcellulose solution were added. The mixture was homogenized in a blender at low speed for $30 \mathrm{~s}$ and stored frozen until isolation of solidsattached microbial pellets. After 1 week, samples for isolation of solid-attached micro-organisms (SAM) were thawed and centrifuged twice, the first time at $500 \mathrm{~g}$ for $10 \mathrm{~min}$ at $4^{\circ} \mathrm{C}$, and then the supernatant fraction was centrifuged at $18000 \mathrm{~g}$ for $25 \mathrm{~min}$ at $4^{\circ} \mathrm{C}$. The pellet obtained was resuspended in $10 \mathrm{ml}$ distilled water and lyophilized.

In addition on the last day, the effluent and the contents of each vessel were collected and mixed. A subsample was centrifuged at $500 \mathrm{~g}$ for $10 \mathrm{~min}$ at $4^{\circ} \mathrm{C}$, and the supernatant fraction was centrifuged again at $18000 \mathrm{~g}$ for $25 \mathrm{~min}$ at $4^{\circ} \mathrm{C}$ to produce a liquid-associated microbial pellet. The pellet obtained was resuspended in $10 \mathrm{ml}$ distilled water and lyophilized.

In all cases, lyophilized pellets were weighed and $\mathrm{N}$ determined by the Dumas procedure (Foss-Heraeus, 1990) and ${ }^{15} \mathrm{~N}$ enrichment by flash combustion with isotope ratio MS (VG Isotech, Middlewich, Ches., UK). The atom \% excess enrichment in samples was calculated from the enrichment in samples minus the enrichment in standard background samples analysed at the same time. Ash and DM in the diet were analysed by the methods of the Association of Analytical Chemists (1975). Neutraldetergent fibre was determined by the methods of Van Soest \& Robertson (1985).

\section{Calculations and statistics}

The proportion of the total digesta $\mathrm{N}$ of microbial origin was estimated by dividing the ${ }^{15} \mathrm{~N}$ enrichment (atom \% excess) of the total digesta from each vessel by the enrichment of the total microbial pellet. Daily microbial N production $(\mathrm{mg} / \mathrm{d})$ was estimated by multiplying total $\mathrm{N}$ production in total digesta by the proportion attributed to the micro-organisms. Daily production of liquid-associated micro-organisms (LAM) was calculated by multiplying the content of $\mathrm{N}$ in the LAM pellet by total weight of LAM recovered. The proportion of bacterial $\mathrm{N}$ in the total microbial pellet, SAM and LAM derived from $\mathrm{NH}_{3}-\mathrm{N}$ was estimated by dividing the ${ }^{15} \mathrm{~N}$ enrichment of bacterial pellets by the enrichment in $\mathrm{NH}_{3}-\mathrm{N}$. Each vessel was considered as an experimental unit. Differences between treatments were compared by an ANOVA table using the Genstat computer program (Lawes Agricultural Trust, Rothamsted Herts, UK; Genstat 5 Committee, 1987).

\section{Results}

Analysis of the chemical composition of the diet (986 g DM/kg fresh weight, $16.9 \mathrm{~g}$ total N/kg DM, $50.6 \mathrm{~g}$ ash/kg DM, $645 \mathrm{~g}$ neutral-detergent fibre/kg DM) supplied to the RUSITEC indicated that, despite repeated washing in the presence of detergent, the neutral-detergent fibre content of the sugar-beet pulp fibre used in the experiment was $<650 \mathrm{~g} / \mathrm{kg}$ and almost $20 \mathrm{~g} / \mathrm{kg}$ of the material was $\mathrm{N}$. 


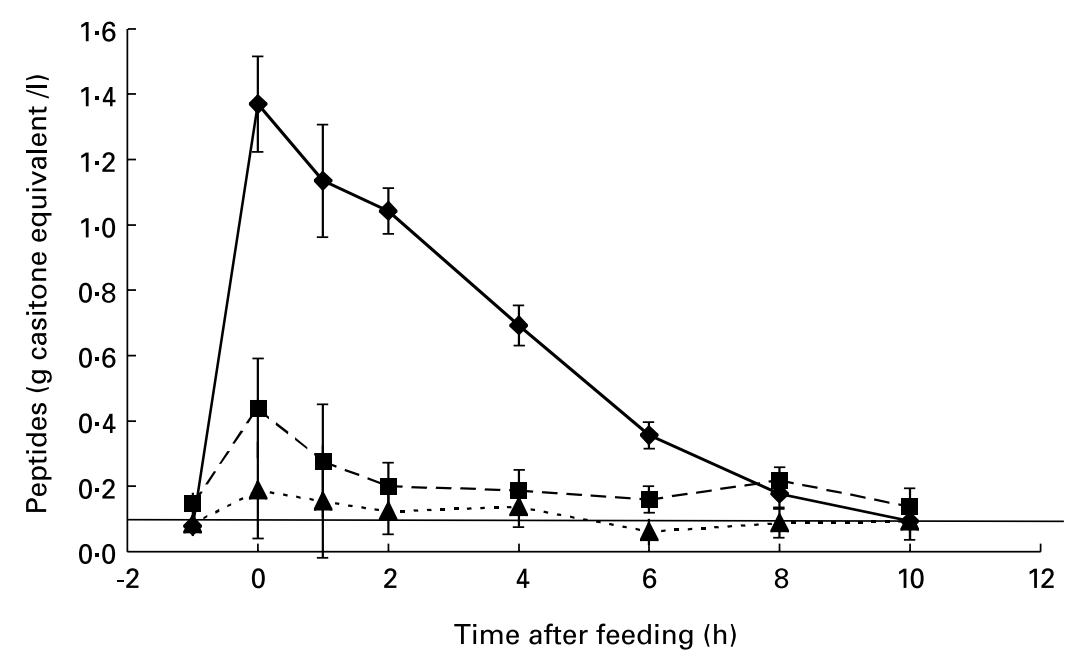

Fig. 1. Influence of different forms and pattern of nitrogen supply on peptide concentrations in RUSITEC. The treatments were: continuous infusion of ammonia (--- $\Delta---)$; peptides added as a single dose at feeding (- - ); peptides infused continuously $(--\square--)$. Vessels were sampled $1 \mathrm{~h}$ before feeding $(-1)$, at the time of feeding $(0)$, and various intervals thereafter. For details of procedures, see p. 74 . Values are means for four vessels per treatment with standard errors shown by vertical bars.

Significantly different patterns of peptide release were obtained with the different treatments (Fig. 1). A peak of peptide concentration occurred in all vessels immediately after feeding. The peptide concentration in vessels with PS treatment was about ten times that in the vessels with AC treatment and triple that in the vessels with PC treatment. Thereafter, the concentration fell in all treatments. The limit of detection of peptides was $0 \cdot 1 \mathrm{~g} / \mathrm{l}$, determined by spiking samples with Bacto ${ }^{\circledR}$ Casitone (Difco Laboratories). In the AC treatment, peptides were detectable for $4 \mathrm{~h}$ after feeding, then fell below the limits of detection. The high concentrations in the PS treatment vessels fell rapidly and were apparently below the limit of detection at $10 \mathrm{~h}$ after feeding and immediately prior to feeding (Fig. 1). Peptide concentrations for the PC treatment never fell below the limit of detection (Fig. 1).

Measured $\mathrm{pH}$ values for PS treatment vessels were higher $(P<0 \cdot 05)$ than in the other vessels (Table 1), but numerically the effect was very small and all $\mathrm{pH}$ values were close to $6 \cdot 7$. Peptides treatments had significantly greater daily production of butyrate $(P<0.05)$, isobutyrate $(P<0.01)$, isovalerate $(P<0.01)$ and valerate $(P<0.01)$ (Table 1). The $\mathrm{NH}_{3}-\mathrm{N}$ outflow was significantly higher with the AC treatment $(P<0 \cdot 01$, Table 1$)$. There were no significant treatment effects on the numbers of culturable total or cellulolytic bacteria (Table 1).

DM disappearance from nylon bags and its resulting degradation equation variables (Table 2) indicated that there were no significant differences between treatments.

${ }^{15} \mathrm{~N}$ enrichment in microbial pellets was lower than that of $\mathrm{NH}_{3}$ (Table 3), indicating that the micro-organisms incorporated $\mathrm{N}$ sources other than $\mathrm{NH}_{3}-\mathrm{N}$. LAM had a greater ${ }^{15} \mathrm{~N}$ enrichment than total micro-organisms or SAM, while the total digesta had an enrichment which was less than half of the extracted total microbial fraction (Table 3). When the proportion of microbial $\mathrm{N}$ derived

Table 1. Effects of different forms and pattern of nitrogen supply on the daily output of volatile fatty acids (VFA) and ammonia nitrogen, the $\mathrm{pH}$ and the numbers of culturable total and cellulolytic bacteria in the rumen simulation technique (RUSITEC) $\dagger$

(Mean values for four vessels per treatment)

\begin{tabular}{|c|c|c|c|c|}
\hline Treatment... & $\begin{array}{l}\text { Ammonia continuously } \\
\text { infused }\end{array}$ & $\begin{array}{l}\text { Peptides continuously } \\
\text { infused }\end{array}$ & $\begin{array}{l}\text { Peptides added } \\
\text { as a single dose }\end{array}$ & SED \\
\hline $\begin{array}{l}\mathrm{pH} \\
\text { VFA output }(\mathrm{mmol} / \mathrm{d})\end{array}$ & $6 \cdot 63$ & $6 \cdot 70$ & $6 \cdot 76$ & $0.048^{*}$ \\
\hline Acetate & $15 \cdot 4$ & $16 \cdot 3$ & 17.9 & $1 \cdot 38$ \\
\hline Propionate & $8 \cdot 1$ & $8 \cdot 0$ & 8.6 & 0.66 \\
\hline Butyrate & $2 \cdot 9$ & 3.5 & $3 \cdot 8$ & $0.28^{*}$ \\
\hline Isobutyrate & 0.2 & 0.7 & 0.6 & $0.04^{*}$ \\
\hline Isovalerate & 1.0 & $2 \cdot 0$ & 1.7 & $0 \cdot 12^{\star}$ \\
\hline Valerate & 1.5 & $2 \cdot 4$ & $2 \cdot 2$ & $0 \cdot 23^{\star}$ \\
\hline Ammonia-N (mg/d) & 180 & 151 & 127 & $11 \cdot 0^{*}$ \\
\hline Total bacteria $\left(\times 10^{8} / \mathrm{ml}\right)$ & $2 \cdot 6$ & $4 \cdot 0$ & 2.7 & 1.45 \\
\hline Cellulolytic bacteria $\left(\times 10^{7} / \mathrm{ml}\right)$ & $2 \cdot 5$ & 3.9 & 3.2 & 0.66 \\
\hline
\end{tabular}

* $P<0.05$

†For details of procedures, see p. 74. 
Table 2. Effects of different forms and pattern of nitrogen on the DM disappearance from nylon bags incubated in the rumen simulation technique (RUSITEC)*

(Mean values for four vessels per treatment)

\begin{tabular}{|c|c|c|c|c|}
\hline \multirow{2}{*}{$\begin{array}{l}\text { Treatment... } \\
\text { Length of incubation }(h)\end{array}$} & Ammonia continuously infused & Peptides continuously infused & Peptides added as a single dose & \multirow[b]{2}{*}{ SED } \\
\hline & \multicolumn{3}{|c|}{ DM disappearance (\%) } & \\
\hline 3 & $13 \cdot 7$ & $13 \cdot 3$ & $13 \cdot 8$ & 1.02 \\
\hline 9 & $16 \cdot 8$ & $23 \cdot 1$ & $22 \cdot 6$ & 3.03 \\
\hline 12 & 33.9 & $29 \cdot 7$ & 31.5 & 4.35 \\
\hline 24 & $37 \cdot 2$ & $41 \cdot 3$ & 41.6 & $5 \cdot 96$ \\
\hline 48 & $53 \cdot 0$ & $49 \cdot 9$ & $52 \cdot 6$ & 1.58 \\
\hline a† & $6 \cdot 2$ & $5 \cdot 0$ & 3.7 & $2 \cdot 61$ \\
\hline $\mathrm{b} \dagger$ & $51 \cdot 3$ & $48 \cdot 7$ & $55 \cdot 8$ & 3.23 \\
\hline$c \dagger$ & 0.0506 & 0.0602 & 0.0564 & 0.0091 \\
\hline
\end{tabular}

* For details of procedures, see p. 74.

†The estimations of DM disappearance at different times were used to derive values describing the shape of the degradation curve: $p=a+b\left(1-e^{-c t}\right)$, where $p$ is the degradation after time $\mathrm{t}$, $\mathrm{a}$ is the intercept of the degradation curve at time zero, $\mathrm{b}$ is the portion of the feed that will be degraded, $\mathrm{c}$ is the rate constant of degradation of b (Ørskov \& McDonald, 1979).

from $\mathrm{NH}_{3}$ in the different fractions was calculated from the enrichments in microbial fractions and the final ${ }^{15} \mathrm{~N}$ enrichment in $\mathrm{NH}_{3}$, it emerged that the proportion of microbial $\mathrm{N}$ derived from $\mathrm{NH}_{3}$ was highest in LAM, particularly in the $\mathrm{AC}$ and PS treatments (Table 4). Total microbial N flow (g/ d) did not differ between the treatments (Table 4). The flow of $\mathrm{N}$ in LAM was higher $(P<0.05)$ for the PC treatment.

\section{Discussion}

The objective of the present experiment was to create different conditions for microbial growth in respect of the availability and timing of supply of pre-formed amino acids. The pre-formed amino acids were supplied in the form of a pancreatic casein hydrolysate, which comprises predominantly peptides of average molecular mass $530 \mathrm{Da}$ with only a small quantity of free amino acids (Wallace, 1992). In accordance with the original method described by Czerkawski \& Breckenridge (1977), bags removed from the RUSITEC after $48 \mathrm{~h}$ incubation were rinsed in a small amount (about $100 \mathrm{ml}$ ) of buffer and the washing returned to the vessel. This procedure is necessary to maintain an active fibre-degrading population in the vessel by transferring attached organisms back to the vessel. This procedure was not carried out on days on which the contents of the bags themselves were used in analysis. The rinsing and return of the washings to the vessel probably explains the small increase in peptide observed after feeding in the AC treatment as peptides from cells lysed during the washing were returned to the vessel. It also explains the larger peak observed in the PC treatment, as the bags for these vessels were rinsed in the PC buffer and thus approximately $0.2 \mathrm{~g}$ Bacto ${ }^{\circledR}$ Casitone (Difco Laboratories) was returned in the wash buffer. Thus the treatments were not isonitrogenous with the PC and AC treatments supplying approximately $308 \mathrm{mg}$ N compared with $280 \mathrm{mg}$ in the PS treatment.

Peptides were present, albeit at very different concentrations, during the first $10 \mathrm{~h}$ of the day in all vessels. No peptides were detected in AC and PS vessels $10 \mathrm{~h}$ after feeding or $1 \mathrm{~h}$ before the next feeding, suggesting that despite the unintentional addition of peptides via the washing the intended experimental design was achieved for $14 \mathrm{~h}$ during the daily cycle. Approximately $2 \cdot 3 \mathrm{~g}$ from a total of $6 \mathrm{~g}$ DM digested over $24 \mathrm{~h}$ can be calculated to have been degraded in that period, representing almost $40 \%$ of the total DM degradation over $24 \mathrm{~h}$. In spite of the availability of peptides in the $\mathrm{PC}$ treatment vessels during this time, no

Table 3. Effects of different forms and pattern of nitrogen supply on different ${ }^{15} \mathrm{~N}$ enrichment (atom $\%$ excess) of microbial pellets (total microbes, solid-associated micro-organisms (SAM) and liquid-associated microbes (LAM)) the ammonia fraction and the total digesta (TD) after the infusion of ${ }^{15} \mathrm{NH}_{3} \mathrm{Cl}$ in the rumen simulation technique (RUSITEC)*

(Mean values with the standard errors for four vessels per treatment)

\begin{tabular}{|c|c|c|c|c|c|c|}
\hline \multirow[t]{2}{*}{ Treatment... } & \multicolumn{2}{|c|}{$\begin{array}{l}\text { Ammonia continuously } \\
\text { infused }\end{array}$} & \multicolumn{2}{|c|}{$\begin{array}{l}\text { Peptides continuously } \\
\text { infused }\end{array}$} & \multicolumn{2}{|c|}{$\begin{array}{l}\text { Peptides added as a } \\
\text { single dose }\end{array}$} \\
\hline & Mean & SE & Mean & SE & Mean & SE \\
\hline \multicolumn{7}{|c|}{ Microbial pellets } \\
\hline TM & 0.0909 & 0.0015 & 0.0945 & 0.0015 & 0.1207 & 0.0043 \\
\hline SAM & 0.0926 & 0.0029 & 0.0931 & 0.0018 & 0.1212 & 0.0163 \\
\hline LAM & 0.1392 & 0.0014 & 0.1045 & 0.0103 & 0.1674 & 0.0096 \\
\hline Ammonia & 0.2018 & 0.0017 & 0.2131 & 0.0027 & 0.2719 & 0.0052 \\
\hline TD & 0.0413 & 0.0008 & 0.0429 & 0.0013 & 0.0569 & 0.002 \\
\hline
\end{tabular}

${ }^{*}$ For details of procedures, see p. 74. 
Table 4. Influence of different forms and pattern of nitrogen supply on the flow of microbial nitrogen and on ${ }^{15} \mathrm{NH}_{3}$ assimilation in the rumen simulation technique (RUSITEC) $\ddagger$

(Mean values for vessels per treatment)

\begin{tabular}{|c|c|c|c|c|}
\hline Treatment... & $\begin{array}{l}\text { Ammonia continuously } \\
\text { infused }\end{array}$ & $\begin{array}{l}\text { Peptides continuously } \\
\text { infused }\end{array}$ & $\begin{array}{l}\text { Peptides added } \\
\text { as a single dose }\end{array}$ & SED \\
\hline \multicolumn{5}{|c|}{ Microbial $N$ flow $(\mathrm{g} / \mathrm{d})$} \\
\hline Total & 0.144 & 0.151 & 0.157 & $0.005 \dagger$ \\
\hline LAM & 0.030 & 0.059 & 0.039 & $0.005^{\star}$ \\
\hline \multicolumn{5}{|c|}{ Proportion of microbial $\mathrm{N}$ derived from $\mathrm{NH}_{3}-\mathrm{N}$} \\
\hline Total & 0.445 & 0.444 & 0.444 & 0.012 \\
\hline SAM & 0.459 & 0.437 & 0.443 & 0.041 \\
\hline LAM & 0.690 & 0.490 & 0.615 & $0.049^{*}$ \\
\hline
\end{tabular}

LAM, liquid-associated micro-organisms; SAM, solid-associated micro-organisms.

${ }^{*} P<0.05$.

$\dagger P<0.061$

$\ddagger$ For details of procedures, see p. 74 .

difference was observed in DM degradation between the vessels. Thus, the availability of peptides did not enhance the digestion of fibre.

These observations are relevant to ideas about synchronizing energy and $\mathrm{N}$ supply to the rumen, which have been studied extensively in vitro (Henning et al. 1991; Newbold \& Rust, 1992) and in vivo (Rooke et al. 1985; Rooke \& Armstrong, 1989; Sinclair et al. 1993; Henderson et al. 1998). It is important to distinguish between $\mathrm{N}$ sources in this discussion. Chamberlain \& Choung (1995) in their review questioned the need for close synchrony between $\mathrm{NH}_{3}-\mathrm{N}$ and energy and proposed that peptides and amino acids should be synchronized with energy, arguing that the peptides can only be detected for a short period of time in the rumen contents (Broderick \& Wallace, 1988), while $\mathrm{NH}_{3}$ is usually available throughout the feeding cycle. In the present study, there was no difference between the PC and PS treatments, indicating that synchronizing energy and peptide supply in these experiments had no benefit.

The counter-argument is, however, that a continuous supply of protein may have been available from the fibre source. In spite of efforts to prepare fibre from the sugarbeet-pulp-feed, a substantial amount of $\mathrm{N}$ remained in the material supplied to the fermenter and thus, some $\mathrm{N}$ was supplied from the diet. Assuming that $\mathrm{N}$ is released from the diet at the same rate as DM loss (and this is almost bound to be an over estimate, given the extensive neutraldetergent fibre washing) then from 12 to $24 \mathrm{~h}$ a maximum of $30 \mathrm{mg} \mathrm{N}$ could be released, that compares to an infusion of about $90 \mathrm{mg} \mathrm{N}$ in the PC treatment over the same time period. However, if microbial synthesis was related to DM degradability then the potential $\mathrm{N}$ released from the plant material would be sufficient to account for much of the microbial $\mathrm{N}$ synthesized between 12 and $24 \mathrm{~h}$ (approximately $38 \mathrm{mg}$ microbial $\mathrm{N}$ if proportional to DM loss). Thus, the possibility that at least some of the microorganisms received a synchronized supply of amino acid-N from the feed can not be ruled out.

Other changes which resulted from the peptides treatments were an increase in certain volatile fatty acids, which would be expected from the fermentation of amino acids (Wallace et al. 1997), and changes in LAM in the
PC treatment which resulted in an increased flow of microbial protein and a decreased incorporation of ${ }^{15} \mathrm{NH}_{3}$. Salter et al. (1979), summarizing data from the literature, found that between 18 and $100 \%$ microbial protein was derived from $\mathrm{NH}_{3}$. Hristov \& Broderick (1996) in vivo and Carro \& Miller (1999) in vitro divided the microbial population into LAM and SAM, and measured the $\mathrm{N}$ coming from the $\mathrm{NH}_{3}$ pool. In the study of Hristov \& Broderick (1996) the LAM accounted for $12 \%$ total bacteria, and the synthesis of microbial $\mathrm{N}$ from $\mathrm{NH}_{3}$ was $10-15 \%$ higher in the LAM than in the SAM. Carro \& Miller (1999) found that LAM accounted for $51-67 \%$ of the microbial population, and the proportion of microbial $\mathrm{N}$ derived from $\mathrm{NH}_{3}$ was between 10 and $30 \%$ higher than in the SAM. Furthermore, Carro \& Miller (1999) found that there was a smaller proportion of microbial $\mathrm{N}$ derived from $\mathrm{NH}_{3}$ in the LAM when peptides and proteins were infused into the RUSITEC vessels, While SAM were unaffected. In the present study, LAM accounted for 20, 39 and $24 \%$ of the total bacterial pool for AC, PC and PS treatments respectively. It was also evident that there was very little change in the proportion of microbial $\mathrm{N}$ derived from $\mathrm{NH}_{3}$ in the SAM in all treatments. On the other hand, although the LAM proportion of microbial $\mathrm{N}$ derived from $\mathrm{NH}_{3}-\mathrm{N}$ in all treatments was bigger than the SAM proportion of microbial $\mathrm{N}$ derived from $\mathrm{NH}_{3}-\mathrm{N}$, there were differences within the treatments: the PC (synchronous) treatment had less uptake of $\mathrm{N}$ from the $\mathrm{NH}_{3}$ pool. These results suggest that perhaps the infused peptides were incorporated by LAM and therefore not available to SAM, or that SAM already had a sufficient supply of peptides from the fibre. This question might be resolved by improved chemical extraction of the fibre, or by using another source of fibre. It may well be the case that micro-organisms digesting certain fibre sources, which have protein closely associated with the fibre, have no need for additional soluble peptides. The effects of microenvironments and nutrient gradients therefore have an important impact on optimizing nutrients for optimal rumen fermentation.

It should be noted, that although ciliate protozoa were present in the initial inoculum, no protozoa were detected in the vessels during the sampling period. The results of 
this present study should therefore be considered entirely in terms of bacterial and possibly fungal metabolism, although the latter were not enumerated.

In conclusion, despite the accidental addition of peptides during the washing of the bags and the possible release of $\mathrm{N}$ from the feed during the incubation, it was obvious that there was no stimulation in any of the fermentation characteristics measured when peptides were added as a continuous infusion compared with a single dose, suggesting little benefit of synchronizing the supply exogenous peptides with energy release.

\section{Acknowledgements}

The Rowett Research Institute receives financial support from Scottish Executive Rural Affairs Department. We thank Nancy Nelson for skilled technical assistance.

\section{References}

Association of Analytical Chemists (1975) Official Methods of Analysis. Washington, DC: AOAC.

Broderick GA \& Wallace RJ (1988) Effects of dietary nitrogen source on concentrations of ammonia, free amino acids and fluorescamine-reactive peptides in the rumen. Journal of Animal Science 66, 2233-2238.

Bryant MP (1972) Commentary on the Hungate technique for culture of anaerobic bacteria. American Journal of Clinical Nutrition 25, 1324-1328.

Carro MD \& Miller EL (1999) Effect of supplementing a fibre basal diet with different nitrogen forms on ruminal fermentation and microbial growth in an in vitro semi-continuous culture system (RUSITEC). British Journal of Nutrition 82, $149-157$.

Chamberlain DG \& Choung JJ (1995) The importance of rate of ruminal fermentation of energy sources in diets for dairy cows. In Recent Advances in Animal Nutrition, pp. 3-27 [PC Garnsworthy and DJA Cole, editors]. Nottingham: Nottingham University Press.

Chen G, Sniffen CJ \& Russell JB (1987) Concentration and estimated flow of peptides from the rumen of dairy cattle: effects of protein quantity, protein solubility, and feeding frequency. Journal of Dairy Science 70, 983-992.

Chikunya S, Newbold CJ, Rode LM, Chen XB \& Wallace RJ (1996) Influence of dietary rumen-degradable protein on bacterial growth in the rumen of sheep receiving different energy sources. Animal Feed Science Technology 63, 333-340.

Conway EJ (1957) Microdiffusion Analysis and Volumetric Error, 4th ed., pp. 277-278. London: Crosby Lockwood \& Son.

Cotta MA \& Russell JB (1982) Effect of peptides and amino acids on efficiency of rumen bacterial protein synthesis in continuous culture. Journal of Dairy Science 65, 226-235.

Genstat 5 Committee (1987) Genstat 5 Users' Manual. Oxford: Oxford University Press.

Cruz Soto R, Muhammed SA, Newbold CJ, Stewart CS \& Wallace RJ (1994) Influence of peptides, amino acids and urea on microbial activity in the rumen of sheep receiving grass hay and on the growth of rumen bacteria in vitro. Animal Feed Science and Technology 49, 151-161.

Czerkawski JW \& Breckenridge G (1977) Design and development of a long-term rumen simulation technique (Rusitec). British Journal of Nutrition 38, 371-384.

Foss-Heraeus (1990) Macro-N Nitrogen Analyzer Instruction Manual. York: Foss-Heraeus.

Henderson AR, Garnsworthy PC, Newbold JR \& Buttery PJ
(1998) The effect of asynchronous diets on the function of the rumen in the lactating dairy cow. Proceedings of the British Society of Animal Science 1998, 19.

Henning PH, Steyn DG \& Meissner HH (1991) The effect of energy and nitrogen supply pattern on rumen bacteria growth in vitro. Animal Production 53, 165-175.

Henning PH, Steyn DG \& Meissner HH (1993) Effect of synchronization of energy and nitrogen supply on ruminal characteristics and microbial growth. Journal of Animal Science 71, 2516-2528.

Hobson PN (1969) Rumen bacteria. Methods in Microbiology 3B, $133-159$.

Hristov AN \& Broderick GA (1996) Synthesis of microbial protein in ruminally cannulated cows fed alfalfa silage, alfalfa hay, or corn silage. Journal of Dairy Science 79, 1627-1637.

Hume ID (1970) Synthesis of microbial protein in the rumen. II A response to higher volatile fatty acids. Australian Journal of Agriculture Research 21, 297-304.

Hungate RE (1966) The Rumen and its Microbes. Davis, CA: Academic Press.

Johnson RR (1976) Influence in carbohydrate solubility on nonprotein nitrogen utilization in the ruminant. Journal of Animal Science 43, 184-191.

Kim KH, Oh YG, Choung JJ \& Chamberlain DG (1999) Effects of varying the degrees of synchrony of energy and nitrogen release in the rumen on the synthesis of microbial protein in cattle consuming grass silage. Journal of Science Food and Agriculture 79, 833-839.

López S, Valdes C, Newbold CJ \& Wallace RJ (1999) Influence of sodium fumarate on rumen fermentation in vitro. British Journal of Nutrition 81, 59-64.

Macaulay Land Use Research Institute (2001) Curve fitting Software for in sacco degradability and in vitro gas production data. http://www.miuri.sari.uk/IFRU/Fcurve.html

McAllan AB (1991) Carbohydrate and nitrogen metabolism in the fore stomach of steers given untreated or ammonia treated barley straw diets supplemented with urea or urea plus fish meal. Animal Feed Science and Technology 33, 195-208.

Maeng WJ \& Baldwin RL (1976) Factors influencing rumen microbial growth rates and yields: effect of amino acids additions to a purified diet with nitrogen from urea. Journal of Dairy Science 59, 648-655.

Maeng WJ, Van Nevel CJ, Baldwin RL \& Morris JG (1976) Rumen microbial growth rates and yields: effects of amino acids and proteins. Journal of Dairy Science 59, 68-79.

Mann SO (1968) An improved method for determining cellulolytic activity in anaerobic bacteria. Journal of Applied Bacteriology 31, 241-244.

McDougall EF (1948) Studies on ruminant saliva. I. The composition and output of sheep's saliva. Biochemical Journal 43, 99- 109 .

Merry RJ, McAllan AB \& Smith RH (1990) In vitro continuous culture studies on the effect of nitrogen source on rumen microbial growth and fibre digestion. Animal Feed Science and Technology 31, 55-64.

Minato H \& Suto T (1978) Technique for fractionation of bacteria in rumen microbial ecosystem. II. Attachment of bacteria isolated from bovine rumen to cellulose powder in vitro and elution of bacteria attached there from. Journal of General and Applied Microbiology 24, 1-16.

Newbold CJ, Williams AG \& Chamberlain DG (1987) The in vitro metabolism of D, L-lactic acid by rumen microorganisms. Journal of the Science of Food and Agriculture 38, 9-19.

Newbold JR \& Rust SR (1992) Effect of asynchronous nitrogen and energy supply on growth of ruminal bacteria in continuous cultures. Journal of Animal Science 70, 538-546.

Ørskov ER \& McDonald I (1979) The estimation of protein 
degradability in the rumen from incubation measurements weighted according to rate of passage. Journal of Agricultural Science, Cambridge 92, 499-503.

Rooke JA \& Armstrong DG (1989) The importance of the form of nitrogen on microbial protein synthesis in the rumen of cattle receiving grass silage and continuous intra-rumen infusions of sucrose. British Journal of Nutrition 61, 113-121.

Rooke JA, Brett PA, Overend MA \& Armstrong DG (1985) The energetic efficiency of rumen microbial protein synthesis in cattle given silage-based diets. Animal Feed Science and Technology 13, 255-267.

Salter DN, Daneshvar K \& Smith RH (1979) The origin of nitrogen incorporated into compounds in the rumen bacteria of steers given protein and urea-containing diets. British Journal of Nutrition 41, 197-209.

Sinclair LA, Garnsworthy PC, Newbold JR \& Buttery PJ (1993) Effect of synchronizing the rate of dietary energy and nitrogen release on rumen fermentation and microbial protein synthesis in sheep. Journal of Agricultural Science 120, 251-263.

Stewart CS \& Duncan SH (1985) The effect of avoparcin on cellulolytic bacteria of the ovine rumen. Journal of General Microbiology 131, 427-435.

Van Soest PJ \& Robertson JB (1985) Analysis of forages and fibrous foods. In Laboratory Manual for Animal Science. Ithaca, NY: Cornell University.

Wallace RJ (1992) Gel filtration studies of peptide metabolism by rumen microorganisms. Journal of the Science of Food and Agriculture 58, 174-184.

Wallace RJ \& McKain N (1990) A comparison of methods for determining the concentration of extracellular peptides in rumen fluid of sheep. Journal of Agricultural Science, Cambridge 114, 101-105.

Wallace RJ, Onodera R \& Cotta MA (1997) Metabolism of nitrogen-containing compounds. In The Rumen Microbial Ecosystem, 2nd ed., pp. 283-328 [PN Hobson and CS Stewart, editors]. London: Chapman and Hall.

Whitehead R, Cooke GH \& Chapman BT (1967) Problems associated with the continuous monitoring of ammoniacal nitrogen in river water. Automation in Analytical Chemistry 2, 377-380.

(

